\section{DA PENA DE MORTE E DA NECESSIDADE \\ DE SUA PROSCRIÇÃO POR CONSTTITUIR UM SUPREMO ATENTADO À CIVILIZAÇÃO}

\section{Érico Maciel Filho}

\author{
Bacharel em Direito. $D_{a}$ Sociedade Riograndense
} de Criminologia.

1 - MARIANO RUIZ FUNES, expressão puríssima da legítima e alcandorada cultura jurídica espanhola, justificou, em uma de suas obras magistrais $\left({ }^{1}\right)$, a intenção de, uma vez mais, discutir em um livro o problema humano, jurídico, moral e sentimental, da pena de morte, tantas vêzes debatido, tão brilhantemente estudado por espíritos de escol e, aparentemente, não mais passível de renovado exame, - e o fêz sob o fundamento de que, ao depois de banida dos Códigos e da prática judiciária, e quando a julgavam todos decadente, "uma nova vida a rejuvenesce, como um enxêrto da barbárie na decadência das idéias morais, como uma lógica conseqüência do absoluto desprêzo de vidas humanas suficientemente mais nobres e úteis que as dos delinqüentes" $\left({ }^{2}\right)$. Com mais flagrante razão, não nos seria lícito invocar diverso fundamento para a apresentação de um tal tema ante tão augusto Congresso de juristas, desprovido, como o somos, da cultura jurídica que justificaria pretensão doutrinária, mas inspirado, como RUIZ FUNES e essa egrégia Assembléia, por êsse sentimento incoercível de amor ao Direito e de repulsa à barbárie que, no dizer insuperável de JIMENEZ DE ASÚA $\left({ }^{3}\right)$, se caracteriza como uma "eterna e formidável aspiração à liberdade"; sentimento e aspiração que, face às reiteradas crises por que tem passado o Direito, no mundo contemporâneo, estão a exigir dos mais doutos, e das eminências, a manifestação final e unânime em prol da humanização progressiva das penas e do genérico e cabal respeito à personalidade humana.

Reúnem-se, em memorável Congresso, as mais brilhantes expressões do Direito continental, pródigos, tais mestres, em ministrar-nos os mais seguros ensinamentos e as mais autorizadas e ma-

(1) Ruiz Funes - Actualidad de la venganza, pág. 98

(3) Asúa - in Actualidad de la vengança, de Funer, pág. 28 duras opiniões, satisfeitos e felizes, nós outros, de ora desfrutarmo dessa gratíssima oportunidade de, como privilegiado auditório, ouvirmos a palavra serena e erudita de tão consagrados professores universitários. E a nossa velha Faculdade de Direito, por ocasião da comemoração dé seu cinqüentenário, engalana-se com a presença de tão augustas figuras e, certamente, glorificar-se-á como cenário eventual de um conclave em que a opinião livre das. Américas haverá de exteriorizar-se na palavra esclarecida dos juristas e dos professôres de Direito, justamente em um momento em que as preocupações e paixöes políticas enceguecem os espíritos, facilitando a observação e contribuindo para a agravação de uma grande e universal crise do Direito.

Propícia é a ocasião, portanto, para que um dos muitos alunos que frequientaram os bancos desta velha Escola, colhendo os fundamentos de um humanismo orientado no sentido do Direito e da Liberdade, venha sugerir a essa Egrégia Assembléia uma renovada afirmação pública de princípios supremos que devem necessàriamente nortear a vida jurídica em uma sociedade suficientemente civilizada.

Não poderíamos nós outros, em consequêencia, deixar de utilizarnos dessa gratíssima oportunidade de, em sugerindo ao Congresse uma tal manifestacão, ouvirmos, finalmente, o verbo autorizado dos mestres, induzindo os presentes à aclamação daqueles princípios que venham a caracterizar-se como juridicamente irrenunciáveis. Outro desejo nos não move, portanto, do que a aspiração de presenciarmos, nesta ocasião festiva, à reafirmação daqueles ideais e princípios que, desde os escritos lapidares de BECCÁRIA, CARRARA e DORADO MONTERO, têm contribuído para a gradativa transformação do Direito Penal vindicativo em uma futura ciência de recuperação dos criminosos, livre já dos prejuízos que ainda a viciam essencialmente e, pelo menos, virtualmente infensa à utilização daqueles métodós repressivos que, pela sua gravidade ou irreparabilidade, caracterizam-se como a própria negação do Direito.

A humanidade contemporânea vive uma existência ensombrecida pela instabilidade das relações sociais, sobressaltada ante o imponderável e o imprevisível das soluçóes progressivamente restritivas dos direitos e garantias individuais, atonita e irrequieta, descrente e desiludida, na contemplaçấo passiva de contínuos e sucessivos avanços e recuos, por vêzes, e paradoxalmente, simultâneos, no sentido do progresso ou da involução, característicos, tais fatos, de uma profunda e manifesta crise do Direito, proclamada, aliás, por todos os juristas e sociólogos contemporâneos. E a civilização do século vinte, edificada por sôbre as ruínas de um passado histórico pródigo em exenplos de grandeza ou miséria moral e jurídica, desenvolve-se em

5 - R D _ - 2 V Vol. 
verdadeiro ciclo ondulatório, ensaiando, por vêzes, soluções já definitivamente proscritas, como que tateando, às escuras, em busca de um. norte jurídico, evidentemente insensível à atração verdadeiramente: norte jurídico, evidentemente insensivel à atração verdadeiramente
magnética que sôbre civilizaçóes anteriores costumara exercer o $D_{i}$. reito.

Sob um tal clima, foi nosso século teatro de uma primeira gran-de comoção universal, cujas conseqüências, funestíssimas, conduziram, finalmente, a já desventurada humanidade, por diversos roteiros, à segunda guerra mundial, restando, dessa hecatombe, por vez talvez final, o reiterado exemplo e a renovada prova de que as solucões violentas ou belicosas 'das diferenças ideológicas \$ẫo, na maioria das vêzes, caminhos que traduzem a fuga ao debate, à compreensão, à solidariedade e à tolerância, impondo a ideologia, não do mais justo" ou do mais acertado, senão que a do mais poderoso.

Ganham atualidade, assim, as idéias que, há tantos anos, defendeu o nosso inesquecível RUY BARBOSA, porisso que a civilização hodierna caminha, não irremediável, mas perigosamente, para a tendência a preferir o direito da fôrça à fôrça do Direito, incapaz de encontrar a fórmula social e internacional da convivência harmônica dos povos e dos cidadãos, propensa à intolerância, avêśsa à díscussão conciliatória, irresistivelmente seduzida pelo critério de justica que em as primevas eras, imperava entre os homens: no grupo social, a rigidez sacramental do pensamento mágico, com a subordinação do indivíduo a todos os tabus impostos pelo viver coletivo; no plano intervicinal, a lei do mais forte que, ao depois de depurada, originou o Talião, ou seja, a primeira teoria penal fundada na preocupação de retribuir o mal com um mesmo mal aparentemente justo, por absolutamente proporcional.

Essa instabilidade da vida internacional, com tôdas as suas variantes, repercute, direta e visivelmente, sôbre a estrutura dos diversos regimes jurídicos particulares, tanto mais quando é notório que, como decorrência da grave e delicada situação internacional, estão as diversas nações compulsòriamente compreendidas em variadas zonas de influência dos países mais fortes e poderosos, - refletindo-se tal circunstância através de uma tendência, normalmente observada em casos similares anteriores, ao agravamento violentíssimo da repressão política, da mesma forma que, como decorrência de um regime de fôrça, qual seja o fascista, na Itália, nasceu um Código Penal autoritário, como reflexo da ditadura política no campo do Direito Público.

Não é nosso propósito, em absoluto, discutir o aspecto político da crise contemporânea, que vem gerando um espírito belicoso e uma preocupação armamentista em todos os países do mundo, - pois julgamos que ciência e política são, presentemente, departạmentos di- versos e, muitas vêzes, antagônicos, do conhecimento e das preocupações humanos. Releva acentuarmos, contudo, que não deixamos de perceber a íntima conexão entre certos ramos do Direito e a Política, - fugindo, entretanto, à aproximação, no caso do Direito Penal, ante o perigo de que, como sói geralmente acontecer, possa o pensamento político preconcebido impor-se à ciência, deformando-a, envilecendo-a, desvirtuando-a em sua grandeza e no seu supremo caráter de afirmação imparcial e desinteressada de verdades úteis ou de soluções conducentes ao paulatino aperfeiçoamento da conduta ou do viver humanos.

Pretendendo fazer apenas obra de ciência, portanto, digamos que a psicologia coletiva do após-guerra, que é a de nossos tumultuosos dias, reflete as conseqüências de sucessivos traumatismos sentimentais e psicológicos, derivados da situação de constante sobressalto em que têm vivido os povos do mundo, sob a grande tensão de uma expectativa reiterada de melhores dias, - quadro êsse que, examinado serena e objetivamente, está a exigir tratamento preferentemente psicológico e reconfortante, quando não psiquiátrico, de grandes massas de população, cuja escassa ou nula cultura foi trabalhada, pelos anos em fora, por uma propaganda belicosa insistente, quando não fanática, cujos efeitos se traduzem preferentemente na acentuação da intolerância e da incompreensão, social e internacional, caminho que, reiteradas vêzes, ademais de gerar condições favoráveis ao desenvolvimento da criminalidade, nos tem conduzido ao primitivismo de, pelo emprêgo da fôrça armada, preferirmos a supressão dos antagonistas à convivência harmônica e construtiva com todos os povos e nações do mundo.

Face a um tão desolador panorama moral e jurídico, motivos não faltam aos sociólogos, aos juristas e aos políticos bem intencionados, para um alarme justificado, para uma profunda e comovida apreensão.

$\mathrm{E}$, se as tentativas, preferentemente político-partidárias, de solução dos problemas mundiais, com o seu partidarismo, com a sua intolerância, com seu sectarismo, e com o seu indiferentismo para com os interêsses comuns de tôdas as correntes de opinião, têm conduzido a civilização moderna por tão tortuosos e fatais destinos, - tempo já é de que os juristas e os pensadores amantes do Direito e da justiça social, - prescindindo dos fundamentos de uma política que desagrega e antagoniza, e abraçando os princípios universalistas de uma ciência que congrega e solidariza os povos e os homens, - propugnem, ante a impossibilidade de impedirem virtualmente a marcha do tempo ou a temporária duração de um "statu quo" injusto e pernicioso, propugnem, dizíamos, pelo menos, pela salvaguarda de alguns dos direitos fundamentais do homem que, quando reconhecidos e aceitos 
pelos governantes, facilitarão, natural e espontâneamente, a marcha do progresso e a natural e pacífica evolução das nações e dos sistemas jurídicos no sentido de formas e soluções mais justas, mais democráticas e mais progressistas.

A complexidade e extensão dos problemas ligados à gravidade da hora presente não comportam exame em um trabalho de tão limitados contornos, destinado à consideração da necessidade de manifestar-se o pensamento jurídico contemporâneo contra a tendência, já crescente, de adoção da pena de morte, como suposta medida repressiva eficaz e admissível em uma sociedade civilizada, - tendo sido feita, anteriormente, uma ligeira esquematização do problema em razão da influência que um tal estado de coisas tem exercido sôbre a involução das normas jurídicas imperantes em diversos países da América e do mundo.

Refiramos, para exemplificar, a utilização, com finalidade política, e em grande escala, da pena de morte, na Alemanha, na Itália e na Rússia, com a parcial atenuante da exaltação dos ânimos, decorrente do estado rveolucionário, mas com a injustificável e duradoura lesão a um direito sagrado, sob a inspiração do pensar dominante $\left(^{4}\right)$; a existência da pena de morte nos Estados Unidos, mesmo depois da abolição dessa penalidade na Rússia Soviética (5); o restabelecimento da pena de morte no Peru $\left(^{6}\right)$; a aplicação, na França, de pena privativa de liberdade com a duração de 53 anos ( 7 ); a utilização crescente da "narcoanálise", pelo emprêgo do "Pentothal", em diversos países do mundo, não com a finalidade de submeter o suspeito a posterior tratamento médico-curativo, senão que com espírito vindicativo e repressivo, - fato que motivou, sucessivamente, o pronunciamento, em contrário, na capital argentina, da "Asociación de Abogados de Buenos Aires" ( ${ }^{8}$ ) e da Direção da "Revista de Derecho Penal" $\left({ }^{9}\right)$, e, na França, por unanimidade de votos, da Academia de Medicina de Paris $\left({ }^{10}\right)$, sob o fundamento de que o emprêgo de tal método altera a personalidade e é pouco seguro em seus resultados, traduzindo violência não permissível para fins repressivo-vindicativos, e sòmente aceitável sob a preocupação curativa $\left.{ }^{11}\right)$; os expurgos, de caráter manifestamente político, nas cátedras universitárias de diversos países; e, finalmente, reiteradas tentativas de imposição, nos regimes democráticos, de governos com po-

\footnotetext{
(4) Ruiz Funes - ob. eit., págs. 151 e segts.; Jimenez de Asáa - Derecho

Ruiz Funes - ob. eit.
(4)

(5) Rev. Brasileira de Criminologia, v. I, fasc. 1, pág. 138.

(6) Rev. de Derecho Penal, v. $5 .$, II, pag. 3 .

(8) Rev. Der. Penal, v. 5. , II, pág. 94.

(10) Rev. Bras. Orim., v. 8. , f. 9. $9 .$, pág. 72

11) Gagnieur, J. P. The Judicial use of psychonarcosis in France - in
}

deres pràticamente discricionários sôbre a vida e a liberdade dos cidadãos, através das já mundialmente famosas "leis de segurança", excepcionais e diretamente atentatórias de todos os direitos que as Constituições democráticas asseguram a todos os cidadãos em os sistemas jurídicos dos países cultos ou, pelo menos, medianamente civilizados.

Renovam-se, assim, pelo ressurgimento das condições favoráveis, os perigos de sucessivas e gravíssimas mutilações ou supressões dos direitos fundamentais do homem, entre os quais o direito à vida e à liberdade são, sem dúvida, os absoluta e decrescentemente preferenciais.

2 - A pena de morte, no passado, constituiu medida repressiva comum, agravada, muitas vêzes, com penas acessórias, cujos efeitos se faziam sentir sôbre os descendentes ou ascendentes do condenado, ou precedida da prática, crudelíssima è selvagem, dos mais atrozes tormentos, entre os quais se tornaram célebres as provas judiciais do torniquete, do ferro em brasa e do combate singular ou contra as bêstas, além da denominada "prova caldária". Tais práticas atingiram seu clímax quando foi instituída e passou a funcionar a denominada "Santa Inquisição" que, segundo algumas opiniões $\left({ }^{12}\right)$, copiou tais métodós dos hábitos dos visigodos, pelo menos em parte. Não obstante deter a primazia, no que diz respeito à aplicação desmedida e incontida de suplícios atrozes às suas vítimas, a Inquisição (13) foi apenas um dentre muitos outros exemplos, porisso que os godos, os romanos, os gregos, os árabes, os germanos, e alguns outros povos, utilizaram-se, em menor escala, é verdade, do barbarismo. Graças a tais requintes de vandalismo, aperfeiçoaram-se os métodos de supliciamento ou de privação da vida dos condenados, surgindo, progressivamente, desde os primitivos tempos, a cruz, a fôrca, a roda, a fogueira, a degola, a guilhotina, o fuzilamento, a eletrocução e, finalmente, os gases letais $\left({ }^{14}\right)$, como instrumentos daquela política repressiva que RUIZ FUNES, com sua inconteste autoridade, denomina "deefsa social pelo terror".

E’ necessário pôr-se em evidência, todavia, que as diversas correntes do pensamento filosófico ou político, examinando, em todos os tempos, a essência mesma de um tal proceder, têm sido inspiradas, na crítica ferrenha, como na defesa intransigente dos defeitos alheios ou próprios, por êsse espírito classista que, desde os tempos do sábio

(12) Alexandre Herculano - História de Portugal, vol. $80^{\circ}$, págs. 157 e segts.

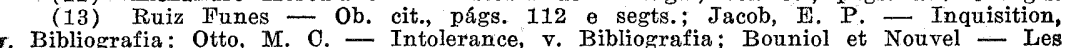
hóresies, v. Bibliografia ; M. Lahy-Hollebecque - La Religion - L'Église, v. Bibliografia: v. I, págs. 319 e segts.
(14). Sutherland - Pr. de Oriminologia, pág. 634. 
fabulista grego, serviu de argumento a uma das mais filosóficas e metafóricas esquematizações da intolerância de quantos criticam em os outros aquilo que nêles próprios lhes deslustra os méritos.

Dessa forma, contemplando os fatos desde um prisma tão sectário, os romanos mataram a Jesus; e os gregos, a Sócrates; e os cristãos, a Bruno $\left({ }^{15}\right)$ e a Antonio José da Silva $\left({ }^{16}\right)$; e os inglêses, ao jesuíta Edmond Campian (17); e os portuguêses, a Felipe dos Santos e a Tiradentes; e os brasileiros e norte-americanos, a infelizes negros'africanos; e os fascistas, aos italianos desconformes; e os nazistas afrialemães ou judeus supostamente não arianos; e os russos do tempo do império, aos revolucionários potenciais; e os bolchevistas da revolução, aos remanescentes monárquicos, - todos êles agindo, segundo têm declarado, em defesa da fé, ou da civilização, ou do Direito, contra os inimigos de deus, da paz ou da sociedade organizada! E, sob a invocação dêsses mesmos e absurdos fundamentos, supliciaram os portuguêses a Felipe dos Santos, sob a forma simbólica do esquartejamento; torturaram os inquisidores a Galileu, determinando, por conseqüência, o falecimento do genial autor dos diálogos em tôrno da teoria de Copérnico; decidiu o papa Estêvão VI desenterrar e salgar o cadáver do papa Formoso, cuja cabeça e dedos foram separados do corpo, para serem atirados ao Tibre $\left(^{18}\right)$; e resolveu a Igreja enforcar o papa Estêvão VI, sob a inspiração do Talião.

Não obstante tais fatos traduzirem, pràticamente, todos êles, uma mesma conduta arbitrária em um clima de terror, esmeraramse, através dos tempos, os romanos, na tentativa de caracterizacãa da conduta de Cristo como criminosá, justificando, assim, a pena atroz que suportou com a salvaguarda dos interêsses do Império Romano; e não menos cuidaram os gregos de explicar a bárbara sentenca im posta ao grande Sócrates; e, com similar intransigência ortodoxafirmaram os dirigentes ; e, com similar intransigência ortodoxa fo $\left({ }^{19}\right)$, ser tão lícito católicos, na palavra de seu maior filósoporisso que o pecador é pior um herege como trucidar um animal, os protestantes inge pior que um bruto e causa maiores danos; e os protestantes inglêses justificaram o assassínio de padres católicos com o argumento da defesa nacional contra os espiões estrangeiros; enquanto que os portuguêses esquartejaram Felipe dos Santos e levaram Tiradentes ao patíbulo sob a invocad argupe dos Santos e fesa da coroa portuguêsa (15) Ernest Trattner - Arquitétos de idéias, pág. 42; F. S. Taylor - Pequena
Hist. da Oiência, pág. 126/127.
(16) Evaristo de

(17) R. Fúlop Miller - Os Járceres e fogueiras da Inquisiçăo, pág. 30 e segts. (18) Ruiz Funes - Ob. Os Jesuístas, pág. 343.

(19) Tomaz de Aquino. Summa. Teológica, quest. LXIV, art. II: - "It ideo,
nvis hominem in sua dignitate manentem occidere sit secundur. huminem peccatorem occidere potest esse bonum; sicut occidere bestiam: peior tamen americanos e brasileiros assassinaram milhares de negros, sob a inspiração de um racismo que, a seu juízo, era um imperativo do trato de uma raça nobre com uma raça inferior e degradada, sob a pressão dos interêsses econômicos; enquanto que os nazistas alemães fundamentavam suas atrocidades com a defesa do Reich ou a purificação da raça ariana, e os fascistas italianos defendiam seu vandalismo com a consideração do supremo interêsse do Estado Fascista, e os bolchevistas russos pretendiam justificar seus expurgos políticos com a invocação do perigo da contra-revolução financiada pelas potências capitalistas.

A intolerância intransigente, inspirando a todos, e a cada um de per si, ergiu em verdade suprema e exclusiva filosofias, crenças religiosas ou regimes políticos que, para os seus adeptos, não seriam passíveis de discussão e simbolizariam a perfeição imutável, cuja defesa e conservação justificariam, a seu juízo, a prática de tôda a sorte de barbarismos e atrocidades contra a heterodoxia recalcitrante no êrro.

Isso não obstante, o absurdo de semelhante posição doutrinária emerge, cristalino, das considerações que vimos de fazer, tôdas elas conducentes à prova de que um tal ponto de vista traduz, apenas, um egoísmo fanático e perverso, gerado na opulência do favoritismo dominante, cego ante a evidência de que, segundo o ponto de vista em que se coloque o ortodoxo inquisidor, operar-se-á uma contínua transmutação da ortodoxia em heresia ou da heresia em ortodoxia, - conducente à compreensão de que, em um mundo civilizado, deve ser possível a coexistência pacífica e harmônica de homens de tôdas as crenças filosóficas, religiosas ou políticas, sob pena de, inevitàvelmente, utilizar-se o poder constituído da opressão e da violência para a obtenção, simplesmente aparente, de uma uniformidade de opiniões. Tal evidência foi enunciada, sob um fino manto de amarga ironia, pelo grande BECCÁRIA, em um dos capítulos de sua obra imortal, nos seguintes têrmos:

"Seria demasiado longo, igualmente, mostrar que, para reunir todos os cidadãos de um Estado numa perfeita conformidade de opiniões religiosas, é preciso tiranizar os espíritos e constrangê-los a vergar sob o jugo da fôrça, embora essa violência se oponha à razão e à autoridade que mais respeitamos, que nos recomenda a doçura e o amor dos nossos irmãos, embora seja evidente que a fôrça só faz hipócritas e, portanto, almas vis" $\left({ }^{20}\right)$.

De tais considerações, entretanto, emerge a caracterização de dois dos fatôres sociológicos que, mais amiúde, têm contribuído para 
a admissão da pena de morte: - a centralização absolutista do poder e, em plano não menos importante, a intolerância, sob todos os seus variados matizes. $\mathrm{E}$, desde o prisma psicológico, aparece em relêvo a evidência de que tôdas essas diversíssimas correntes de opinião, ante a impossibilidade de consecução de uma catequese políticofilosófico-religiosa pacífica e fundada no livre debate das idéias, passaram a agir, sob a influência do mêdo, da colera ou da vingança com a intolerância e o despotismo que, em determinados momentos, converteram os juízes, no dizer de VOLTAIRE, em homens que não haviam nascido para ser magistrados, pôsto que a natureza os havia destinado à missão de verdugos.

$\mathrm{E}$ vivem, assim, os povos, desde priscas eras, creditando aos demais a primazia na barbárie e o requinte na sua execução, - incapazes de compreenderem, ou hipócritas na compreensão de que justamente as correntes de opinião mais acerbamente críticas ao regime jurídico-social de certos povos são as que, em diversos momentos históricos, desencadearam, sucessivamente, verdadeiras torrentes de opressão sôbre as maiorias inermes ou desafortunadas, ou sôbre as minorias altivas e resistentes à generalização da intransigência e do barbarismo.

3 - A pena de morte tem sido utilizada, por diversos povos: e em diversas épocas, tanto para a repressão dos delitos comuns como para a dos crimes chamados políticos. Detenhamo-nos, pois, inicialmente, na consideração de seu emprêgo como medida repressiva comum, inserta em diversos códigos penais de páíses civilizados.

4 - A corrente de doutrina favorável à manutenção da pena de morte tem em GABRIEL TARDE sua expressão sociológicojurídica mais acabada, porisso que o brilhante professôr e penalista francês discutiu e fundamentou suas conclusões no terreno estritamente social-criminológico $\left({ }^{21}\right)$. E, partindo de tais fundamentos, deslocou TARDE o problema da pena de morte do plano teológicofilosófico, para situá-lo entre os temas discutidos pela sociologia. e a criminologia, rumando, assim, no sentido da orientação de GAROFALO, LOMBROSO e FERRI, e fazendo a defesa da tése lombrosiana da inutilidade social de certos delinqüentes incorrigíveis, ponto de vista êsse que o sociólogo francês levou às suas últimas consequências, em contrário de LOMBROSO e, particularmente, de FERRI, cujas reservas, a tal respeito, sempre foram manifestas.

Renasceu, portanto, com GABRIEL TARDE, a teoria da utilidade social da pena de morte, e o penalista gaulês cuidou afanosamente de fundamentar sob alicerces mais sólidos êsse método re-

\footnotetext{
(21) G. Tarde - La Peine de Mort - in "La Philosophie Pénale", páoss. 533 e segts.
}

pressivo que, como bem acentua RUIZ FUNES, teve sua origem em um fenômeno de automorfismo.

Sob uma tal orientação, ampliou GABRIEL TARDE, desmedidamente, as idéias de LOMBROSO, cuja ponderação, relativamente a tal problema, obteve, inclusive, a aprovação, de TAINE, em carta que dirigiu ao antropologista italiano.

A verdade, porém, é que a corrente favorável à manutenção da. pena de morte nas legislações e na prática judiciária tomou novos. rumos, depois que TARDE ocupou-se, em sua "Filosofia Penal", do palpitante tema, - afirmando, não só a legitimidade do último. suplício, senão que a sua manifesta utilidade social.

Presentemente, portanto, são preferentemente os seguintes os. argumentos apresentados por essa corrente doutrinária, em favor da utilização da pena de morte:

I - Ser a pena mais intimidante e, em conseqüência, à que mais contribui para demover as pessôas da prática do crime (prevenção geral);

II - Ser mais econômica que a pena de prisão;

III - Ser um excelente meio de seleção artificial;

IV - Caracterizar-se, pela sua irreparabilidade, como uma. garantia contra o perdão judicial ou a possível fuga: dos condenados.

5 - O exame de todos êsses argumentos já foi feito, anteriormente, por expressões categorizadas do Direito Penal e da Criminologia contemporâneos, tôdas elas orientadas no sentido do humanismo e do respeito aos direitos fundamentais dos cidadãos, merecendo especial menção os estudos de BENTHAM (22), na Inglaterra, sôbre os aroumentos favoráveis e contrários a tal instituição; o trabalho de PUGLIA ( $\left.{ }^{23}\right)$, suscinto, mas esclarecedor; as consideraçóes. de CARRARA $\left({ }^{24}\right)$, insertas em seu Programa de Direito Criminal; o excelente estudo do Prof. CUELLO CALÓN, desenvolvido em sua Penologia ( ${ }^{25}$ ); e, de um modo geral, os estudos feitos por BECCARIA, DORADO MONTERO, FLORIAN, JIMENEZ DE ASÚA e MARIANO RUIZ FUNES, o último dos quais dedicou a quadra atual de sua vida à tarefa nobilíssima de, desde o exílio, ministrar a uma geração sacrificada e apreensiva os sábios conselhos de um mestre eminentíssimo, cuja vida exemplar é tôda uma afirmação de amor ao direito e à liberdade e de repulsa à crescente utilização.

(22) Bentham - Oeuvres, II, págs. 67 e segts.

Penale, pács, 356 o segto

(24) F. Carrara - Programa, Parte geral, vol. II, ns. 659 e sgts.; ṕ́gs, 20 e segts. 
de métodos repressivos já proscritos pelos povos cultos, - devendo a ciência, e a própria humanidade, a tais eminências, a gratidão perene com que serão recompensados não sòmente por haverem destruído, inquestionàvelmente, os artificiosos argumentos dos partidários da última pena, senão que, ademais disso, pela constância e altivez com que se dedicaram à salvaguarda dos basilares princípios da Civilização. Aos penalistas espanhóis, em particular, principalmente a JIMENEZ DE ASÜA e MARIANO RUIZ FUNES, deve ser creditada a solução final e humana dêsse palpitante pro* blema, perspicazes e eruditos, como o foram, no exame da crise do Direito Penal contemporâneo, e na crítica dêsses princípios hedonísticos que, inspirando o regimen vigente, refletern-se diretamente sôbre a administração da Justiça, subordinada, como ainda está, antes aos interêsses particulares do Estado, do que às necessidades fundamentais da própria sociedade.

6 - Na consideração do problema que nos prende a curiosidade e nos exalta a humana sensibilidade, deveremos, preliminarmente, acentuar que o fato de haver um delinqüente cometido um homicídio não poderá justificar, moral e jurìdicamente, a prática de um segundo assassínio, legalizado sob a forma da permissão e tolerância oficial, porisso que, com o auxílio de elementares considerações lógicas, poder-se-á evidenciar que constitui um absurdo inominável pretender o Estado arrogar-se o direito de punir um ato penalmente ilícito, para, logo depois, e em meio a lúgubre cerimonial, repetir, não só impune, mas solene e ruidosamente, o crime nefando. Tal é, inquestionàvelmente, o ponto de vista que aos caracteres bem formados impõem o moral e o Direito, sob a inspiração de princípios éticos, jurídicos ou sentimentais.

$\mathrm{E}$ tal evidência cresce de ponto quando se desce à consideração de que, salvo nos regimes despóticos ou ditatoriais, o denominado interêsse social descansa, necessàriamente, na premissa fundamenta da crescente melhoria das condições de existência de cada indivíduo com o mínimo de sacrifício dos direitos individuais, em nome dos quais os homens, cordata e altruisticamente, se têm mostrado dispostos à renúncia de parte de sua liberdade, não em benefício de um Estado divinizado, senão que da felicidade dos demais cidadãos!

Está, portanto, o Direito dominado por um elevado espírito finalista, dirigido, precípua e firmemente, no sentido de impedir as mais leves transgressões, mesmo aos direitos secundários, como os patrimoniais, numa perene afirmação de um supremo espírito de eqüidade e de justiça.

E a justiça, pelo menos em sua imaculada essência, desconhece os privilégios, e os "distingos" sutis, e os artifícios com que os condutores de povos, envilecendo-a, tratam de chegar a um conceito de interêsse coletivo que, em realidade, traduz, apenas, a preocupação de defesa da classe dominante e da ordem social que a alicerça.

Atualizam-se, assim, as nobres palavras que o talentoso ELLERO legou a posteridade:

"Negamos que, para garantir a segurança social, seja necessária a pena de morte; mas, mesmo supondo que o fôsse, é necessário que digamos que, para nós, o fím da sociedade está subordinado ao fim do homem; que a personalidade coletiva daquela não pode, de maneira alguma, absorver a personalidade individual dêste; jamais o homem pode converter-se em instrumento do bem de qualquer agrupação humana. Pereça a sociedade, se isso é possível, mas fique a salvo o homem" $\left({ }^{26}\right)$.

O interêsse social, portanto, clama, antes de mais nada, pelo aperfeiçoamento dos métodos de assistência a todos os membros da sociedade, - e nunca pelo menosprêzo ostensivo do mais sagrado dos direitos, que é o direito à vida.

$\mathrm{E}$, como a noção de justiça evoluiu, sociológica e històricamente, no sentido da progressiva diminuição das restrições impostas ao viver coletivo, particularmente no Direito repressivo, desde o tabú talionar às modernas concepções humanitárias, - não é concebível que o preço a ser pago pelo indivíduo, em um sistema penal retributivo, por uma lesão grave aos direitos alheios ou ao interêsse da coletividade, possa ser traduzido na outorga, em favor do Estado, não mais do seu patrimônio ou de sua liberdade, senão que daquele bem supremo que é condição mesma do eventual exercício de todos os direitos.

$\mathrm{E}$, se a consideração dos interêsses fundamentais do homem veio dar margem històricamente, à formação do Direito, cuja missão, nos países cultos, é a proteção do indivíduo e da sociedade, e não do Estado todo-poderoso personificado em elites ou favorecidos será porventura admissível a temerária assertiva de que a maneira de restabelecer o equilíbrio jurídico violado seja agravá-lo ainda mais em oficializada e rubra orgia de sangue? E poderá a humana compreensão aceitar a argumentação de que a maneira de defender a sociedade do extermínio, frente aos assassínos, seja assassiná-los?

Diversos homens de bem assim o entenderam, convencidos, pelo menos concientemente, de que o fim da última pena era nobre e socialmente apreciável. E, nesse caso, como em tantos outros, se nos depara o curioso paradoxo de que, muitas vêzes, os mais acir-

\footnotetext{
(26) Cit. por Cuello Calón - Penologia, pag. 58.
} 
rados defensores da pena de morte são justamente aquêles que com maior energia e coragem opõem-se, intransigentemente, aos métodos eutanásicos, sob a alegação de que a vida humana é um bem supremo contra o qual não é lícito atentar-se, mesmo com fundamento na defesa de preferenciais interêsses, sempre subalternos e jurìdicamente mais débeis do que o da conservação da existência humana; posição doutrinária essa que, ineludivelmente, evidencia que, sob muitos aspectos, estão com a razão os modernos psicólogos, quando afirmam que a defesa da pena de morte, como método penal-repressivo, está apenas concientemente inspirada pelo interêsse da defesa social, sendo muito diversas as determinantes inconcientes de uma tal atitude.

Face ao exposto anteriormente, entretanto, não nos parece difícil o salientarmos a contradição flagrante e inexplicável entre os pontos de vista retro referidos. Isto porque a "morte por piedade", ou seja, o homicídio eutanásico, se resume na supressão voluntária de uma vida humana, sob o impulso do mais alevantado e puro dos sentimentos humanos, que é a piedade, sentimento êsse a que - sempre se associa a solidariedade humana, - agindo o matador sob a coação violentíssima das súplicas de um sofredor incurável ou agonizante, almejando, apenas, pôr têrmo, não mais a uma vida humana, senão que aos quase restos mortais de uma existência incapaz de sentir, de locomover-se, de auferir a liberdade, de viver, em suma, conciente e humanamente; enquanto que o Estado, ao executar um criminoso, ceifa, quase sempre, uma vida plena, exuberante, por vêzes não perigosa, não raro um inocente, teòricamente inspirado pela Defesa Social, mas pràticamente no exercício de um suposto direito de fria e desapiedadamente, desmandar-se em criminosas chacinas, impondo uma falsa defesa social pelo terror.

Em razão disso, enquanto o homicida piedoso opta por uma dentre as duas únicas alternativas possíveis, preferindo a altruística à sádica, a nobreza e a compaixão à indiferença, - o Estado prefere, entre diversíssimas possibilidades mais humanas a solução atrocíssima, o homicídio legalizado, o critério repressivo menos eficaz, o mais bárbaro, e o mais atentatório de todos os princípios em nome dos quais a Justiça persegue implacàvelmente os homens delinqüentes.

O problema da admissão da Eutanásia envolve consideraçóes e aspectos de suma gravidade, entre os quais avulta, em primeiro plano, o extraordinário progresso da Medicina que, nos dias correntes, facilitou a cura de moléstias até então incuráveis ou gravíssimas; of ertando a esperança de que, em futuro não muito remoto, pouquíssimos sejam os males para os quais se não possa dispor de um tratamento manifestamente eficaz. Face a essa circunstância, não deixa de ser também temerária a admissão do homicídio piedoso, porquanto sempre existirá a possibilidade de que, quase de imediato, descubra a terapêtica o método de cura de diversas moléstias tidas, até entäo, por incuráveis. E, em tal hipótese, ter-se-ía dado morte a quem, um dia após, poderia dispor de novos recursos para a mais sagrada das batalhas em defesa do mais sagrado dos direitos: a luta pela vida.

Mas, se tais fatos nos não autorizam a reconhecer a legitimidade presente do homicídio piedoso, - quais os fundamentos jurídicos-sociais que poderão autorizar-nos a admitir a utilização da pena de morte, cujos efeitos são similares aos da eutanasia; cujos fundamentos, contrariamente aos desta, são a vingança, o rancor, o sadismo ou o mêdo; cuja utilidade jurídico-social é manifestamente nula; cujas consequiências são, ademais de irreparáveis, em relação ao executado, perniciosas, socialmente, pelo efeito que produzem sôbre a opinião pública em geral?

De outra parte, estando incorporadas à moderna doutrina criminolóica contemporânea a discriminação detalhada das causas econômico-sociais e psicológicas da delinqüência, e mantendo-se a maioria dos governos indifertne à solução de problemas que, diretamente, afetam a etiologia da criminalidade, tais como o pauperismo, a vadiagem, a infância desamparada, o alcoolismo, o jôgo, a prostituição, a falta de assistência médica e hospitalar, o baixo nível de instrução do povo, e tantas outras, - poderá atribuir-se ao Estado autoridade suficiente para, sob a invocação do interêsse social, levar ao patíbulo, ou à eletrocução, as verdadeiras vítimas da desorganização social?

Um "não" enfático e comovido certamente brotará dos lábios, não só dos juristas como dos humanitários, apercebidos, que estaráo, de que o Estado, em a maioria dos casos, assemelha-se àquelas fêmeas fáceis e tentadoras, de que nos fala MANCI (27), cujos obscuros desígnios se resumem no desejo de, ao depois de facilitarem aos homens tôdas as franquias, através das maiores seduções, leválos à barra dos tribunais, para que expiem o delito de que foram, em realidade, as verdadeiras vítimas.

Falece, assim, ao Estado, poder ou autoridade para, conspurcando o nome e a idéia da Justiça, dispor discricionàriamente de vidas humanas, sob a alegação de estar defendendo o interêsse público, porisso que, hodiernamente, exige a civilização que se não sacrifique uma existência em holocausto à metafísica noção de sociedade, não fundada sôbre a idéia basilar de que a nação está constituida pela comunidade de homens, cuja valoração e prosperidade individual é que poderá contribuir para a grandeza nacional.

(27) Filippo Manci - Reatti Sessuali, págs, XIII/XIr. 
Razão assiste, portanto, ao eminente RUIZ FUNES, quando, irônica e sagazmente, refuta a infeliz argumentação do Prof. CARNELLUTTI, que ousou comparar a pena de morte à desapropriação por utilidade pública $\left.{ }^{28}\right)$ !

7 - Tôdas essas observações, ditadas por um natural sentimento de justiça e humanidade, encontram eco em as mais modernas teorias psicológicas, particularmente as defendidas pelas duas principais orientações da psicologia profunda.

Efetivamente, as teorias de FREUD, ADLER e tantos outros. psicólogos, consubstanciadas nas doutrinas da psicanálise e da denominada psicologia individual, esclarecem à nossa geração que os. motivos que aparentemente impulsionam o delinquiente ao crime nada mais são do que uma verdadeira máscara a encobrir quer a exteriorização de violentas tendências, inconcientes e reprimidas, quer um terrível e quase invencível complexo de inferioridade, que conduz o delinqüente potencial ao desalento - mas que o torna passível de tratamento reeducativo e re-socializante, que o tornará parcial ou totalmente útil à sociedade em que, presentemente, vive ou vegeta.

O Prof espanhol EMILIO MIRA Y LOPEZ, com seu extraordinário poder de síntese, resume, em umas poucas páginas, a essência: da interpretação psicanalítica do delito $\left({ }^{29}\right)$, esclarecendo, esquemàticamente, os caracteres de três tipos de delinqüentes cuja conduta pode ser explicada, sumária e claramente, pela doutrina de FREUD, mas salientando, objetivamente, que um não menor grupo de criminosos procede sob o impulso de reações diversas que, na opinião do Prof. JIMENEZ DE ASÚA, são satisfatória e plenamente explicadas pela teoria de ADLER $\left({ }^{30}\right)$, salvo em escassas hipóteses que raramente ocorrem.

E se não renova, absolutamente, com a consideração de tais teorias, a tese antropológica do "criminoso nato", fundada na admissão, presentemente inaceitável, de teorias biotipológicas absolutas e infalíveis; aceita-se, isso sim, a possibilidade de que determinados e pouco numerosos delinqüentes manifestem uma tendência verdadeiramente irresistível ao crime, não como decorrência de sua particular constituição anatômica, senão que em conseqüência de uma violência excessiva dos impulsos do "ego" que não permitem derivação nem repressão e se descarregam diretamente, sob a forma delitual $\left({ }^{31}\right)$; ademais disso, é reconhecida a notória influência das

(28) Ruiz Funes - Ob. cit., págs. 166 e segts.
(29) Mira y Lopez - Los fundamentos del psicoa

(30) Mibenes de Asúa Los fundamentos del psicoanalisis, pág. 153 e segts.

(30) Jibenes de Asúa - Psicoanálisis Criminal, pág. 309.
(31) Mira y Lopez - ob. cit pá condições endocrinológicas de um paciente sôbre o seu caráter que por sua vez, influi substancialmente sôbre a sua conduta honesta ou anti-social; fora dêsses casos, ou paralelamente com os seus fatôres determinantes, acolhe-se a enormíssima influência de fatores psicológicos ou sociais sôbre a personalidade humana, quer sob a forma de retificação e dominação de tendências anti-sociais, pela educação generalizada, quer sob o aspecto mais geral da manifestação simbólica e mascarada dos instintos primitivos rebelados contra o sistema social, gerando a inadaptação do indivíduo aos costumes sociais ou à ordem jurídica estabelecida e vigente.

As conclusões da psicanálise permitiram a formulação científica de uma observação que, desde longa data, se impunha à consideração humana; - $a$ verdade de que o ato de matar, em bom número de casos, seja êle praticado por um delinquiente ou autorizado pelo Estado, obedece a impulsos e tendências psicológicas primitivas, particularmente à satisfação do sadismo e do espírito de vingança. Ao depois de acurados estudos e observações, ALEXANDER e STAUB (32) confirmaram as primitivas conclusões de FREUD, chegando, juntamente com os modernos psicólogos, à conclusão de que, em não poucos casos, se não poderá fugir à necessidade de compreensão de que a psique do delinqüente desadaptado e anti-social é muito similar, em sua estrutra, à de todos aquêles que, em muitas oportunidades e circunstâncias, clamam pela expiação e pela repressão bárbara e inclemente do delito, ou se prestam à execução dêsses mesmos métodos expiatórios e vindicativos. Essa observação científica, em verdade, tem sido confirmada por alguns criminologistas, que referem diversos casos em que a execução de um condenado determinou, no público, não sentimento de terror ou medo, senão que generalizadas emoções sádicas $\left.{ }^{(33}\right)$.

Outra importante conclusão, tanto da psicanálise, como, particularmente, da psicologia individual, - é a da inutilidade da pena de morte, afirmada pela psicanálise em razão de que os criminosos que geralmente cometem os delitos mais bárbaros se não detêm ante a consideração da pena e, em muitos casos, a desejam inconscientemente; confirmada pela psicologia individual porisso que entendem os seus doutrinadores que os criminosos, sendo desalentados ou inadaptados, não devem ser punidos, senão que submetidos a tratamento re-educativo e reconfortante.

Tais ensinamentos, portanto, demonstram, desde o prisma científico, que o Estado, futuramente, não mais disporá de um fundamento jurídico para o ato de punir os delinqüentes, porisso que se

(32) Alexander-Staub - o criminoso e seus juízes. 
aperceberá, oportunamente, de que a sua missão se resume em farilitar a readaptação social daqueles que se desviaram do bom caminho, na maioria dos casos antes pela pouca assistência que lhes é ministrada do que pelo desejo gratuito de praticar o mal. E tôdas essas conclusões da ciência põem em relêvo a evidência de que a prevenção generalizada do crime dispensará, futuramente, as medidas repressivas, da mesma forma que provam, cumprida e irretorquivelmente, que a mais humana das prevenções se resume em prover o Estado à eliminação dêsses influxos do mundo circundante que provocam a reação criminosa dos delinqüentes $\left(^{34}\right)$ ou ao tratamento da personalidade ou das insuficiências ou desadaptaçóes psíquicas dos homens propensos a reagir anti-socialmente frente a influxos não suficientemente fortes para arrastar os demais cida'dãos à senda do crime. Um tal proceder traduzirá, em sua fiel caracterização, $\mathrm{o}$ desejo de prevenir, inexistente no sistema talionar - da pena de morte, que exercita a prevenção especial sob o critério deshumano da eliminação de um delinqüente mediante a prática de ato similar ao punido, e tenta exercer a prevenção geral, não pela progressiva eliminação das causas da criminalidade, senão que pelo terror supostamente intimidante.

8 - Em que pese, contudo, a procedência científica dos argumentos anteriormente expostos como fundamento da oposição ao suposto direito estatal ou social de por-se têrmo a uma existência humana - professôres haverá que, em razão de suas crenças religiosas ou filosóficas, ou de sua posição frente às diversas escolas de Direito Penal, discordarão da essência mesma da psicologia freudiana ou adleriana, ou, simplesmente, de suas conclusões, e, em razão disso, estarão a exigir de nós outros um fundamento mais objetivo para a tese da inutilidade da pena de morte como medida repressiva pretensamente intimidante. A História, antes que outra qualquer fonte, tem ministrado o reiterado exemplo de que a repressão violenta das idéias, pelo poder político, contribui, justamente, para o fortalecimento de tais pontos de vista, que sobrevivem, sobranceiros, até os nossos dias. Os exemplos talvez mais decisivos que fortalecem uma tal afirmação são o do cristianismo, que ganhou em prestígio com a perseguição fanática que the moveram os imperadores romanos; o da heresia, que multiplicou-se em proporção ao aumento progressivo da atividade inquisitorial; e o da Revolução Francêsa, como manifestação de um povo contra o absolutismo dos reis que, longe de acovardá-lo, o revoltou.

Mas haverá de ser a própria Criminologia que, na palavra de seus mais conspícuos cultivadores, evidenciará que, pelo exame dos

\footnotetext{
(34) Jimenez de Asúa - Psicoanalisis Oriminal, págã 258, a: 61 .
}

*dados estatísticos, é inadmissível a hipótese de que a utilização da pena de morte contribua para a prevenção gerai da criminalidade, sendo mesmo provável que o fenômeno inverso seja o verdadeiro. E dizemos "provável" porisso que, desde os estudos de PARMELEE (35) a té os de VON HENTIG $\left({ }^{36}\right)$ e SUTHERLAND ( $\left.{ }^{37}\right)$, têm os estudiosos reconhecido que as oscilações nos índices da criminalidade obedecem à variação das causas etiológicas" da delinqüência, entre as quais se não pode incluir, em absoluto, ausência da pena capital na legislação. $E^{\prime}$ o que já afirmava, no comêço do século, o sagaz MAXWELL ( $\left.{ }^{38}\right)$. E SUTHERLAND, em obra recentíssima $\left({ }^{39}\right)$, refere interessantes estatísticas, obtidas nos Estados Unidos, algumas das quais revelam que os índices mais altos de criminalidade são encontrados nos Estados do sul, onde a pena de morte é admitida, enquanto que outras, obtidas em um mesmo Estado da União, abolicionista, por exemplo, variam enormemente, segundo são obtidas em um ou outro município ou condado, - havendo, entretanto, uma profunda similitude entre os dados estatísticos obtidos em "conties" de similares características étnico-econômico-sociais, mesmo quando situados em afastados e divérsos Estados da União americana. O mesmo criminologista, em sua alentada e erudita obra $\left({ }^{40}\right)$, demonstra, com um exemplo concreto, o valor apenas relativo das estatísticas que, tomadas como dados absolutos pelos partidários da pena de morte, em certos países, conduziram a doutrina, por falsos caminhos, a conclusões erradas. Diz, textualmente, o Prof. SUTHERLAND: "A legislatura de Illinois aprovou, em 1917, um projeto de lei abolindo a pena de morte, mas o governador vetou-o e êle não se transformou em lei. Os assassínios aumentaram muito nesse Estado depois de 1917. Se o projéto se tivesse transformado em lei, muitas pessoas e muitos jornais sem dúvida teriam visto nisso a prova absoluta de que a abolição da pena de morte aumentou a taxa de assas"sínios" ( $\left.{ }^{41}\right)$

Medindo, todavia, serenamente, o valor de tais dados estatísticos, afirma o professor americano, acordemente com a opinião unânime dos demais tratadistas, nesta matéria, o ponto de vista de que os índices delituais dependem antes de mais nada das condições etiológicas favoráveis à prática do crime, mas, apesar disso, observa imparcialmente que:

"Os resultados das comparações relativamente grosseiras feitas nos Estados Unidos são confirmados pelas

(35) Parmelee - Criminología, pág. 400 e segts.

(36) Von Henting - Criminología, pág. 245 e segt

(37) SUTHERLAND - Princípios de Criminologia, pág. 635 e segts.

(38) J. Maxwell = Le crime et la société,
(39) Sutherland $=$ Ob. e loc. cit.
(40-41) Sutheriand - Ob. cit., pág. 638.

6 - R. D. - 2..$^{\circ}$ Vol. 
comparações feitas nos países europeus. Em média, os países europeus que aboliram a pena de morte têm taxas mais baixas de homicídio do que os países que a conservam. Os países escandinavos, que aboliram a pena de morte, têm taxas de homicídios de cerca de metade das da Inglaterra, que a manteve" ( $\left.{ }^{42}\right)$.

Todos êsses estudos, portanto, poderão conduzir apenas a duas conclusões alternativas: ou se não admite a interferência, positiva ou negativa, da pena de morte, na prevenção do crime, cujas causas são muito diversas e complexas; ou ter-se-á que admitir, forçosamente, face aos dados expostos, que a existência da pena de morte na legislação incita os delinqüentes potenciais à prática do crime.

Em qualquer das duas hipóteses, portanto, ruirá por terrra, uma vez mais, a tese deshumana de que o preço da felicidade social, como acreditam certos povos primitivos, seja o sacrifício de certas vidas humanas, imoladas ante o altar de uma decadente civilização.

9 - Dois últimos argumentos utilizados por alguns autôres em defesa da instituição da pena de morte devem ser sumàriamente examinados, como complemento do breve estudo que vimos de fazer: o primeiro dêles, equiparando a pena capital à intervenção de um cirurgião que, pela ablação de um órgão, salva o organismo; o segundo, considerando o problema do interêsse econômico do Estado que, com a utilização crescente da pena de morte, deixará de ser obrigado a manter, em penitenciárias ou manicômios, os delinqüentes perigosos ou incorrigíveis.

$\mathrm{O}$ argumento referido inicialmente fundamenta-se, inquestionàvelmente, em um sofisma grosseiro, porisso que a função do médico e, particularmente, de um cirurgião, está intimamente ligada à salvaguarda da vida do paciente, em cujo benefício poderá, quando não mais forem úteis as soluções clínicas, recorrer à via operatória. E, em tal sentido, é notória a cautela com que os médicos, em tôdas essas ocasiōes, tratam de evitar, dentro dos limites da prudência, a ablação de um órgão, cuja função, evidentemente, é, senão imprescindível, pelo menos muitíssimo importante para o normal funcionamento de todo o organismo.

$\mathrm{Na}$ aplicação da pena de morte, contràriamente, prescinde o Estado da valoração do componente celular, que é o homem, e, ademais disso, fugindo a tồdas as soluções mais humanas, sábias e científicas, - empreende a tarefa de destruir uma vida humana, sem um objetivo social definido, desde que, como já foi referido, a utilização

\footnotetext{
(42) Sutherland - Ob. eit., pág. 637.
}

da última pena só ocasiona prejuízos ao organismo social e, em particular, aos componentes individuais da sociedade. Por todos êssés motivos, a missão do médico e a do verdugo, pelos séculos em fora, se não prestarão a confusões ou assimilações grosseiras, plena de humanismo, solidariedade e altruismo, a primeira, prenhe, a segunda, das mais baixas e sórdidas tendências do espírito humano.

A segunda objeção, anteriormente invocada, assemelha-se às considerações já citadas do Prof. CARNELLUTTI, e caracteriza-se como uma ofensa ao sentimento de humanidade de todos os homens de caráter, incapazes de mercantilizar de tal forma o valor da vida humana, em benefício de cofres públicos enriquecidos, justamente, com a laboriosa ação de muitas dessas pessoas que, por fatal desgraça, haverão de onerar os orçamentos deficitários dos países chamados cultos.

10 - Quando não fossem suficientes todos os anteriores argumentos para evidenciar a inutilidade e os gravíssimos inconvenientes da utilização da pena de morte, uma consideração, certamente, bastaria, para congregar a gregos e troianos, a positivistas, clássicos, técnico-juristas, deterministas e livre-arbitristas, na luta contrária à pena capital; e tal consideração não constitui, entretanto, novidade, nem em Penologia, nem na doutrina geral da Criminologia, e se resume na argüição, não só da possibilidade, senão que da ocorrência, não muito rara, dos chamados erros judiciários.

Efetivamente, se de per si constitui um barbarismo o ato de assassinar-se a um assassino, sob a inspiração pouco mascarada do sentimento de vingança ou do espírito do Talião, monstruosidade maior certamente será o privar-se a um sêr humano do direito de viver, quando êsse suposto delinqüente fôr um inocente. A situação será similar à que se analisa no problema da admissibilidade da Eutanásia, com a agravante de que são muito mais comuns os êrros judiciários do que as grandes descobertas científicas que conduzem à salvação de doentes até então incuráveis.

Não poucos são os juízes que, apercebendo-se da tremenda responsabilidade que sôbre seus ombros recai, muito e cautelosamente pesam as circunstâncias e as provas, antes de prolatarem, no juízo criminal, uma sentença condenatória. No silêncio do gabinete, empreendem a rude e terrível tarefa de traçar um novo rumo a uma existência humana, eventualmente condenada a muitos anos de privação de liberdade. E, todos, ou quase todos êles, o fazem com critério, e com honestidade, e com um marcado senso de responsabilidade. Mas a maioria dêles, também, privada, como o está, de todos os recursos periciais ou psicotécnicos que a ciência pôs à disposição da criminologia, - incidirão involuntàriamente no êrro, seguindo as pegadas fatais da meretriz das provas, ou, em determinados casos, apoiando-se sôbre o que parecia ser uma prova pericial irrefutá- 
vel $\left({ }^{43}\right)$. Em todos êsses casos, a retificação futura e possível do êrro devolverá à verdadeira vítima, que é o supôsto delinquiente, o saldo depreciado de uma existência livre. Mas, quando a morte, imposta cruelmente, ceifar uma vida inocente, desaparecerão tôdas as esperanças de uma rehabilitação nobilitante, e pesará sôbre as conciências bem formadas todo o remorso decorrente da prática de um ato selvagem e tràgicamente inútil. Essa possibilidade, não tão rara como poderá supor-se, taxativamente condena, desde o prisma moral e jurídico, uma pena irreparável, porisso que, como já o acentuara PRINS ( $\left.{ }^{44}\right)$, "sendo a justiça humana relativa, necessita de penas relativas, que admitam graus e eventualmente a reparabilidade. A pena de morte participa do absoluto.

Não oferece recurso algum contra o êrro judiciário, sendo certo que os homens são falíveis, os êrros judiciários possíveis, e a história nos oferece numerosos exemplos dêles"

Para tais fundamentos, se a sabedoria popular, antes que o Direito, já aconselhava que seria preferível absolver um culpado do que condenar um inocente, é tempo, talvez, de que a dolorosa experiência suportada estòicamente pela humanidade, em sua aventura rumo à civilização, frutifique na compreensão de que mais vale arriscar-se a sociedade à possibilidade de que um delinqüente venha a foragir-se e cometer eventualmente um crime do que tentar a prevenção inútil de crimes possíveis com atos criminósos efetivos, muitas vezes dirigidos contra vítimas inocentes, em sádicas demonstraçồes de barbarismo.

11 - Repele, pois, a nossa compreensão, a utilização da pena de morte, para a punição dos crimes comuns. E, com mais relevante razão, a abomina, como método repressivo dirigido contra a delinqüência política. Isto porque, se não podemos admitir a sua utilização para a eliminação dos delinqüentes pròpriamente ditos, quase todos êles desadaptados e nocivos à ordem social, pelo menos temporàriamente, - com muito maior fundamento não a poderemos conceber como castigo a ser aplicado a homens que, via de regra, segundo o exemplo histórico, são os verdadeiros precursores das idéias novas ou das reformas sociais salutares, quando não as únicas vozes que se opõem à tirania ou aos governos despóticos, em defesa da Liberdade.

Cabe aqui, a consideração do critério que, modernamente, e desde os memoráveis estudos de JIMENEZ DE ASUA, que desenvolveu uma tese embrionária de GAROFALO, preside à aplicação racional

(43) Elbridge $W$. Stein - Handwriting testimony in a criminal conviction and the disbarment of a lawyer - in J. of Criminal Law and Crim., v. 39 , pág. 519. das penas, e, futuramente, haverá de condicionar a utilização das. das delinqüente: - a perigosidade. E se evidencia necessária tal consideração simplesmente porque a perigosidade resume o índice potencial de inadaptabilidade ou agressividade do delinqüente às condições sociais imperantes, e facilita o estabelecimento do binômio criminoso-sociedade, desvalorizando, pelo menos sob o atual critério retributivo $\left({ }^{45}\right)$, a conduta do delinqüente, em confronto com os cânones sociais de conduta jurídica, porisso que sua atuação esteve condicionada a móveis determinantes subordinados a instintos, ou sentimentos, ou sensações, todos êles alheios a um altruismo inspirado pelo interêsse mesmo da sociedade. Distingue-se, assim, o regicida que mata por ódio pessoal daquele que, sob a insinuação da conveniência de eliminar-se um tirano, dirige a conspiração em virtude da qual vem a ser assassinado um monarca, - o primeiro obedecendo a instintos anti-sociais e egoistas, o segundo orientado, muitas vezes, por motivos nobilíssimos. Perigoso, criminològicamente, o primeiro, à sociedade; perigoso, politicamente, o segundo, ao Estado. Propenso, o primeiro, ao escárneo público e social; destinado o segundo, em alguns casos, à consideração e ao respeito das gerações vindouras.

Não defendemos, neste ponto, a tese de que todo criminoso político ou revolucionário seja, necessàriamente, um ser superior, intangível e perfeito, pois é notório que, em muitos casos, podem agir ilegal e anti-jurìdicamente; limitamo-nos, apenas, a estabelecer, com a possível clareza, a distinção existente entre uma reação anti-social, lesiva da sociedade, e algumas formas de reação manifestamente antiestatais, dirigidas contra o poder consticuido, quando absoluto e tirânico, - reação essa que foi a de todos os mártires que a civilização cultua, ao depois de civilizações e governos anteriores e extintos ao terem reprimido em lúgubres festins de chamas ou de sangue.

Os governos democráticos, em razão de sua própria essência constitucional e popular, jamais precisarão utilizar a pena de morte para a repressão de delitos políticos, posto que serão êles muito raros e poderão ser reprimidos, presentemente, com as penas de privação de liberdade ou com a deportação. Os governos totalitários, em troca, certamente sentirão a necessidade ineludível de uma repressão violenta à reação popular contra a tirania, mas, mesmo assim, sacrificarão, inútil e continuadamente, vidas humanas preciosas, sem obterem a almejada estabilidade da ordem política imposta e, o que é mais importante, sem conseguirem destruir a crescente resistência da maioria democrática do povo. É esta a velha lição da históriá, 
que foi apanhada magnificamente no metafórico relato de JEREMIAS BENTHAM ${ }^{\left({ }^{46}\right)}$

Não padece dúvida que, sob as presentes condiçôes sociais, a repressão do delito, comum ou político, será sempre levada a efeito, nos países civilizados, com um critério vindicativo. Mas é hoje, também, pacífica a compreensão de que, mesmo em se reconhecendo a necessidade da repressão, pelo interêsse da Defesa Social, - é manifestamente inútil o emprêgo da pena de morte, porisso que as penas privativas da liberdade substituem, com flagrante vantagem, a pena capital.

E cabe aqui o salientar-se, como já o fizeram, sagazmente, JIMENEZ DE ASUA ( ${ }^{47}$ ) e ROBERTO LYRA ( ${ }^{48}$ ), desenvolvendo considerações fundamentais sôbre a crise do Direito Penal contemporâneo, que êsse dịreito repressivo imperante em quase todos os povos é, como já o haviam salientado anteriormente VON JHERING ${ }^{49}$ ), GUMPLOWICZ, STEIN, BOVIO, MENGER, VAHRGA, VACCARO, LORIA e MOLINARI, um direito de classe, instituido, preferente e inconcientemente, para a defesa da classe dominante, e, só sencundàriamente, para a tutela dos interêsses de tôda a sociedade. A observação de tal fato vem sendo feita, em obras de Direito, desde o tempo em que MONTESQUIEU escreveu o seu "De l'esprit des lois", e encontra em VON JHERING um expositor brilhante, suficientemente perspicaz para salientar o que êle próprio denomina

"contraste surpreendente que existe entre as legislações penais, pelo que diz respeito à doçura e à severidade das penas",

sob a preocupação de defesa do que caracteriza como sendo o "princípio vital particular do Estado" que, em cada um dos casos concretos, conduz os legisladores à decretação de normas penais severíssimas para a repressão daqueles atos que contrariam ou ameaçam os princípios, mesmo anti-jurídicos, em que o Estado se baseia, ao passo que, para os outros delitos, socialmente mais graves, mostra

"uma indulgência tal que, por vêzes, manifesta um contraste bem extraordinário" $\left({ }^{50}\right)$.

(46) Bentham - Théorie des peines e des récompenses, pág. 73 : "Il faut même observer, relativement à ces délits politiques, que si la mort délivre d'un homme dân. méditer que celui d'un vieil donnant des successeurs plus redoutables. C'est un mot ì lés mains de ses enémis: lé bourreaun venait dd'abattre gue tête: on était tombé entre sanglante: "Regarde, malheureux, la tête de ton fils. - "- Mon fils, répondit-il, a plus

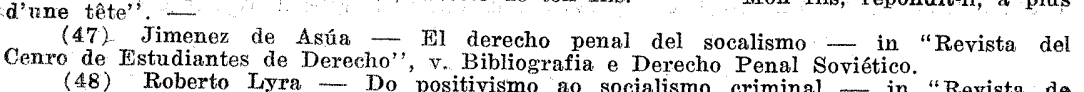
(48) Roberto Lyyra - Do positivismo ao socialismo criminal - in "Revista de erecho Penal", v. 5.o, págs. 145 e seguintes, Tómo I.
Tais observações, profundamente objetivas, facilitam, no estudo da repressão dos chamados delitos políticos, a incorporação de mais um preponderante móvel que, indiscutivelmente, impulsiona o poder contido de tal repressão: - a defesa, não necessàriamente dos interêsse da sociedade em geral, senão que, em muitos casos, da classe dominante e que dispõe do poder.

Essa circunstância contribui, inquestionàvelmente, para reforçar a argumentação de que, se é inadmissível a pena capital para a repressão dos crimes comuns, todos êles lesivos dos interêsses sociais reconhecidos legalmente como jurídicos, - haverá de sê-lo também, ineludível e forçosamente, na repressão dos crimes políticos, destinada, preferentemente, à defesa dos interêsses do grupo dominante, e não da coletividade.

12 - Refiramos, ainda, para finalizar, que, hodiernamente, estẫo na ordem do dia os denominados "crimes contra a humanidade", ou seja, aquela categoria de delitos bárbaros que, via de regra, são praticados por dirigentes de grandes massas humanas, ou por seus subordinados, contra grupos numerosíssimos ou classes inteiras de homens, com o emprêgo de tormentos atrocíssimos e selvagens ( ${ }^{51}$ ). Tais crimes foram praticados, preferentemente, pelos nazistas alemães e pelos japoneses, na última guerra mundial, - e deram motivo a que os países aliados, logo de vencida a guerra, instituissem tribunais para a punição de tais criminosos, utilizando, a tal efeito, em larga escala, a pena de morte (geralmente, por enforcamento). Surge, portanto, uma vez mais, a oportunidade de discutir-se se, face à gravidade de tais delitos, será, ou não, admissível a utilização da pena capital $E$ como decorrência, renova-se, também, a ocasião de reafirmarmos que a maneira de desviar-se o povo alemão, como alguns outros, da senda do imperialismo e da atrocidade deverá fatalmente resumir-se em uma intensa e bem orientada campanha de reeducação, dirigida no sentido dos princípios humanísticos e civilizadores, com prescindência dêsse método que, justamente na Alemanha, impulsionou o Estado e a Sociedade pelos sendeiros do terror e do crime generalizado.

Ademais disso, o critério que presidiu à punição dos responsáveis por crimes contra a humanidade foi, pelo menos em parte, um critério faccioso e preferentemente político. Isto porque, si não é possível negar-se que, tanto em Nuremberg como em Tókio, foram condenados muitos dos grandes criminosos de guerra, com plenitude

(51) V. sôbre a conceituação de "crimes contra a humanidade: B. B. Ferencz Nurnberg trial procedure and the rights of the accused - io Journal of criminal law and
criminology, vol. 39 , págs. 144. e. segts.; Quincy Wright - comentário - in loc. eit eximinology, vol. 39 , págs. 
de defesa e garantias processuais, - não é menos verdade que não chegaram a ser levados a tais tribunais diversos dos mais graduados responsáveis pela prática dêsses atos deshumanos, tais como o imperador do Japão que, como figura divinizada, foi o principal responsável pela conduta de suas tropas, que obedeciam cegamente suas determinações.

Foram poupados, também, milagrosamente, alguns generais alemães que, segundo noticiaram as fontes bem informadas, servem de assessores militares ou técnicos, aos russos ou aos nórte-americanos, no belicoso planejamento de uma paz duradoura.

Caracterizam-se, portanto, alguns dêsses julgamentos, como apreciações facciosas do pensar dominante, na inconciente defesa e preservação dos elementos úteis à estabilidade da ordem social constituida. E chegamos, assim, à paradoxal verificação de que, enquanto em Nuremberg e Tokio foram cominadas penas relativamente brandas contra alguns dos responsáveis pela morte de dezenas de pessoas. ou pela tortura de outras tantas, nos Estados Unidos poderá ser levado à cadeira elétrica o responsável pela prática de uma "felony". Não vai nessa crítica a sugestão de que, com base em a política cri-. minal americana, se passe a fuzilar todos os grandes criminosos, senão que, como é evidente, a aspiração a que, sob um critério humanista, seja banida a pena de morte de todos os códigos e da prática judiciária de todos os povos do mundo. Isto porque, examinando-se os métodos utilizados na última guerra por quase todos os beligerantes, métodos êsses de destruição em massa e indiscriminada, como os bombardeios aéreos, os gases letais e a bomba atômica, - chegar-se-á forçosamente à conclusão de que tão bárbaros métodos de combate e de destruição das vidas de homens, mulheres e crianças, indefesos, falta autoridade moral suficiente para, em nome de um espírito de humanidade, condenar à morte o mais temivel dos seus semelhantes. E, ademais disso, a execucão de tais homens axacerbará o sentimento nacional dos povos vencidos, contribuindo para a repetição histórica dos cataclismas guerreiros e da destruição em massa. Será êsse o caminho que nos guerreiros reito Penal Internacional, conduzirá os homens à fraternidade universal? Assim o cremos, sinceramente, desde que nos prova a História e nos grita a conciência que nenhum fim justifica o discricionário emprêgo dêsses meios cruéis que, paulitinamente, arrastam a humanidade e a civilização à beira do abismo!

13 - Proclamamos, assim, acompanhando a opinião do eminente criminologista inglês, que foi PARMELEE, a grande verdade que pretendeu resumir nas seguintes palavras:
"Es altamente necesário establecer que no debe existir excusa, en tiempo de paz, para la penalidad suprema. En tales casos sirve solamente como baluarte para la: tiranía y como un obstáculo para el progreso político. Ninguna forma de Gobierno que necesite apoyarse en la ayuda de la pena de muerte es digna de existir. Un Gobierno que descansa sobre el deseo del pueblo y que es responsable ante la oluntad de sus conciudadanos, puede dispensar bien esta penalidad" $\left({ }^{52}\right)$.

14 - Chegamos, assim, ao depois de tão breves consideraçóes, ao final de nossa tarefa, e à oportunidade de sugerirmos a essa Egrégia Assembléia de Juristas a aprovação dos princípios humanitários anteriormente expostos, que pretendemos consubstanciar em a seguinte Tese:

"O CONGRESSO JURIDICO, reunido em Pôrto Alegre, por ocasião da comemoração do cinqüentenário da Faculdade de Direito, - condena e repele a pena de morte, como método punitivo-repressivo de quaisquer atividades delituosas, recomendando a supressão de tal pena dos Códigos Penais, e a absoluta abstenção de seu uso, por contrariar o interêsse social e o sentido da Civilização".

15 - Tal é a modesta colaboração de quem, desde os bancos universitários, vislumbrou sempre no Direito êsse sentido humano que valoriza, intransigentemente, a vida e a liberdade dos cidadãos, considerada a primeira como a existência aureolada pelo exercício de todos os direitos que dignificam a personalidade e facultam o desenvolvimento contínuo do progresso e da civilização, rumo a êsse ideal, considerado utópico por tantos escritores, de uma sociedade presidida pela concórdia, pela tolerância e pela solidariedade.

$\mathrm{Na}$ impossibilidade em que nos encontramos de transformar, presentemente, o direito punitivo naquele "Direito protetor dos criminosos" de que nos fala o verbo sublime de DORADO MONTERO, deveremos, pelo menos, consolidar os progressos e as conquistas da civilização, entre os quais figura, em plano proeminente, a decadência e supressão da pena de morte, como método repressivo.

Somos um dentre aquêles que, sob a inspiração das modernas conquistas da ciência, acreditam na gradativa superação dos prejuízos sociais que assentam nos privilégios e na incompreensão do seme-

(52) Parmelee - Criminología, pág. 408. 
Thante valor social de tôdas as vidas humanas, perseguindo o ideal que, com invejável constância, tem sido defendido, em escritos lapidares, pelos penalistas ibéricos, verdadeiros artífices, na América, da difusão, profusa e brilhante, dos princípios basịlares da ciência criminal do porvir.

Utilizamo-nos da magnífica oportunidade, em conseqüência, para Tendermos, comovidamente, homenagem aos lídimos representantes da legítima e autêntica cultura jurídica espanhola, a êsses brilhantes professôres que, emergindo de entre uma geração cujo caráter foi plas mado em meio a tormentosas lutas fratricidas, - e afastados do sa grado torrão natal -, souberam, com sobranceira galhardia, dignificar as já tão decantadas tradições da Espanha, e, com insuperáve brilho, elevar aos pináculos da glória a ciência dos delitos e das penas e os princípios do humanismo e da Civilização.

Fazemos nossas, assim, e já como finais, as palavras daquele talento espanhol que, predicando nas Américas, dignificou tôdas as cátedras de nossas Universidades e lançou o germen fecundo dêsse idealismo que frutificará, algum dia, na realidade augusta de um mundo penal melhorado, em que sejam os homens irmãos, e saibam compadecer-se da desgraça alheia, e compreendam a necessidade de uma mútua assistência, que se elevará por sôbre a caridade numa lu minosa marcha em busca da Justiça:

"Yo voy más allá. Todo Derecho será cancelado y sólo la Criminología, ciencia causal explicativa, completada con remedios, imperará en el futuro. Acaso se me diga que ésta es una utopía. Rechazo la imputación: de ningun ideal puede decirse que es ajeno a este mundo. Utopía pareció antaño el hecho de volar con aparatos más pesados que el aire; utopía era el cisne negro, pero se descubrió Australia y aparecieron esas aves sombrías, y se ingenió el hombre y los aeroplanos surcan el espácio". $\left.{ }^{53}\right)$.

\section{REFERENCIAS BIBLIOGRAFICAS}

ALEXANDER, F. - STAUB, H. - O CRIMINOSO E SEUS JUízES, traducão de Leonídio Ribeiro, Editora Guanabara, Rio, 1934;

LEXANDER, Leo - WAR CRIMES AND THEIR MOTIVATION, in "J. of Criminal Law and Criminology", vol. 39, pags. 298 e segts., Chicago Inlinois, 1948;

- DESTRUCTIVE AND SELF-DESTRUCTIVE TRENDS IN CRIMINALIZED SOCIETY, in "Journal of Criminal Law and Criminology" vol. 39 , pags. 553 e segts:

- THE MOLDING OF PERSONALITY UNDER DICTATORSHIP, in "Journal of Criminal Law and Criminology", vol, 40 pags. 3 e segts A MRANTE, Jurandyr - PENA DE MORTE, Livraria H. Antunes-Editora, Rio, 1938;

ANDRADE, AImir de - DA INTERPRETAÇ̃o NA PSICOLOGIA, Liv. José Odimpyo-Editora, Rio, 1936;

- A VERDADE CONTRA FREUD, Schmidt-Editor, Rio, 1933

AOUNNo, Tomás de - SUMA TEOLóGICA, tradução de Alexandre Corrêia, Liv. Editora Odeon, S. Paulo, 1936;

ASÚ, Luiz Jiménez de - LA LEY Y EL DELITO, Editorial "Andrés Bello". Caracas, 1945

- PSICOANÁLISIS CRIMINAL, cuarta edición, Editorial Losada, Buenos Aires, 1947;

- RTELEXIONES SOBRE EL ERROR DE DERECHO EN MATERIA PENAL, Libreria "El Ateneo", Buenos Aires, 1942;

- DERECHO PENAL SOVIETICO Tipográfica Editora Argentina S. A., Buenos Aires, 1947

- PROBLEMAS DE DERECHO PENAL, Editorial "La Facultad", Buenos Aires, 1944

- IIBERDADE DE AMAR E DIREITO A MORRER, tradução de Benjamim do Couto, Livraria Clássica Editora, Lisboa, 1929;

- O ESTADO PERIGOSO, tradução de Catoira-Blay, Edições e Publicações Brasil, S. Paulo, 1933;

CRONICA DEL CRIMEN, $3 .^{n}$ edición, Editora Inter-Americana Buenos Aires, 1945;

- ML DERECHO PENAL DEL SOCIALISMO, in "Revista del Centro Fistudiantes de Derecho", tomo 17, n.o 80, pags. 96 e segts., Montevideo;

- ORf́genES DE LA FILOSOFIA PENAL LIBERAL, in "El Criminalista", vol. 4. ${ }^{\circ}$, pags. 9 e segts., Eiditorial "La Ley", Buenos Aires, 1944

- INDAGACIÓN SOBRE EL FUNDAMENTO DEL DERECHO DE PENAR, in "El Criminalista", vol. 4..$^{\circ}$, pagis. 39 e seg.;

- EL DRAMA SILENCIOSO DE UNA VIDA SABIA, in "El Criminalista", vol. $4 .^{\circ}$, pags. 73 e segts.;

ILAS ESCUELAS PENALES A LA LUZ DE LA CRITICA MODERNA, in "El Oriminalista", vol. $4 .^{\circ}$, pags. 89 e seg.

LIBERTAD Y DERECHO PENAL in "El Criminalista", vol 4.o, pags. 121 e segts.;

- LA REFORMA PENAL, in "El Criminalista", vol. 4. ${ }^{\circ}$, pags. 139 e segts.;

BARRETO, Adalberto - A FAVOR DA PENA DE MORTE, in Revista Brasileira de Criminologia, vol. 3. ${ }^{\circ}$, Fasc. $6 .^{\circ}$, pag. 33 ; 
BASTIDE, Roger - SOCIOLOGIA E PSICANÁLISE, Instituto ProgréssoEditorial, S. A., S. Paulo:

ECCARI Cesare - DOS DELITOS E DAS PENAS, tradução de Paulo M. Oliveira, Athena Editora, Rio, 1937;

BELLONI, Giulio A. - PENA, - verb. in "Dizionario di Criminologia" de Florian-Niceforo-Pende, vol. II, pags, 654 e isegts.; Editrice Francesco Vallardi - Milano, 1943;

BENTHAM, J. - THÆORIE DES PEINES E DES RECOMPENSES, - in "Oeuvres", vol. II, Sociéte Belge de Librairie, Bruxelles, 1840;

BITTENCOURT, C. A. L. - AINDA A PENA DE MORTE, in Revista de Direito Penal, vol. $4 .^{\circ}$, pags. 272, Jacinto-Editor, Rio;

BODIN, Jean - CONTRE FREUD, Masson \& Cie. - Éditeurs, Paris, 1926

BONGER, W. A - INTRODUCCIÓN A LA CRIMINOLOGIA, versión de Antonio Peña, Fondo de Cultura Economica, Mexico

BOUNIOL, J. - NOUVEL, E. - LES HËRESIES, in "Histoire Universalle Quillet', Tome II, pags. 286 e segts., Librairie Aristide Quillet, Paris, 1938

CANTÚ, César - HISTóRIA UNIVERSAL, vol. VII, pags. 68 e sg., tradução de Manuel Bernarides Branco, 2. ${ }^{a}$ edição, Lisboa, 1877

ARRARA, Francesco - PROGRAMA DEL CURSO DE DERECHO CRI MINAL, Parte General, vol. II, pags. 20 e segts., $\$ \$ 659$ e segts., Editorial Depalma, B. Aires, 1944

CUELI, CAL6N, Eugenio - PENOLOGIA, Editorial Reus, Madrid, 1920 - DERECHO PENAL, quinta edición, 1er. Tomo. pags. 631 e segts., Bosch-Casa Editorial, Barcelona, 1940;

DAFLBERG, Gunnar - A NEW METHOD IN CRTME STATSTICS AP PLIED TO THE POPUTATTON OF SWEDTN, in "Journal of Criminal Law and Criminology", vol 39 ,

DAUTRICOURT, Joseph Y. - CRIME AGAINST HUMANITY, in "Journal of Criminal Law and Criminology", vol. 40, pags. 170 e segts.

I TULLIO, Benigno - ETIOLOGIA CRIMINALE, verb. in" "Dizionario di Criminologia", de Florian-Niceforo-Pende, vol. I, pags. 326 e segts;

ERENCZ, Benjamin B. - NURNBERG TRIAL PROCEDURE AND THF RICHTS OF THE ACOUSED, in "Journal of Criminal Law and Criminology", vol. 39 , pags. 144 e segts;

FERRI, Enrico - SOCIOLOGIA CRIMINAL, versión de Antonio Soto y Hernandez, Centro Editorial de Gongora, Madrid;

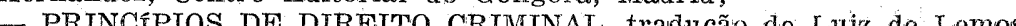
Sobrinho, Livraria Acadêmica, S. Paulo, 1931;

- HOMICIDIO-SUICIDIO, traducción de Concha Peña, Exitorial Reus, S. A., Madrid, 1934;

- EL HONICIDA EN LA PSICOLOGIA Y EN LA PSICOPATOLOGIA CRIMINAL, traducción de Masaveu-Aguilar, Editorial Reus, Madrid, 1.930;

FLORIAN, Eugenio - PARTE GENERAL DEL DERECHO PENAL, traducción de Ernesto Dihigo, Imprenta "La Propagandista", La Habana, 1929;

FREUD, S. - PSICOPATOLOGIA DE LA VIDA COTIDIANA. traduccion de Ballesteros-Torres, Biblioteca Nueva, Madrid, 1929;

- TOTEM Y TABu, Ditorial Pax, Samiago, 1936

- PSTCOLOGIA DE LA VIDA EROTICA, Editorial Osiris, Santiago;

- INTRODUCCION A LA PSICOANALISIS, Ediciones Ercilla - Santiago, 1936;
GAGNIEUR, J. P. - THE JUDICIAL USE OF PSYCHONARCOSIS IN FRANCE, in "Journal of Criminal Law and Criminology", vol. 40, pags. 370 e segts;

GAMELR0, Mario - A FAVôR E CONTRA A PENA DE MORTE, in Rev. Brasileira de Criminologia, vol. 2. ${ }^{\circ}$, fasc. 2, pg. 148;

GARMA, Angel - PSICOANALISIS DE LOS SUEÑOS, Editorial El Ateneo Buenos Aires, 1940.

GAROFLLO, R. - CRIMINologIA, seconda edizione, Fratelli BoccaEditori, Torino, 1891 :

GRUNHUT, Max - PENAL REFORM. Clarendon Press, Oxford, 1948

GUERRA JUNQUEIRO - SOBRE A PENA DE MORTE, in "Revista de Direito Penal", vol. 4. ${ }^{\circ}$, pags. 248, Jacinto-Editor, Rio;

GUZOT - DE LAA PENA DE MUERTE EN MAAERIA POLITICA, traducão espanhola, 1943 .

GUNBURG, Niko - LES TRANSFORMATIONS DU DROIT PENAL, Librairie Félix Alcan, Paris, 1938;

TIG, Hans Von - CRIMINOLOGIA, traducción de Diego Abad de Santillán, Editorial Atalaya, Buenos Aires, 1948,

HERCULANo, Alexandre - HISTóRIA DE PORTUGAL, Tomo $88^{\circ}$, Livraria Francisco Alves, Lisboa, 1916;

ORNEY, Karen - EL AUTOANALISIS, versión de León Mirlas, Editorial Poseidón, Buenos Airres;

DUNGRIA, NeIson - O DIREITO PENAL AUTORITẢRIO, in "Questões Jurídico-Penais", pags. 23 e segts., Livraria Jacinto-Editora, Rio, 1940; MPALLOMENI, G. B. - ISTITUZIONI DI DIRITTO PENALE, pags. 97, Unione Tipografico-Eiditrice Torinese, Torino, 1921;

NGENIEROS, José - CRIMINOLOGIA, 6." edición, L. J. Rosso \& Cia., Buenos Aires, 1916;

MACOB, E. F. - INQUISITION, in "Encyclopaedia of the Stocial Sciences", vol. 8. ${ }^{\circ}$, pags. 61 e segts., The MaclMillan Co., New York, 1937;

JHERING, Ruidolf Von - A LUTA PELO DIREITO, tradução de João de Vasconcélos, Livraria Francisco Alves, Rio, 3. ${ }^{n}$ edição;

JUNG, C G - LA PSIQUE Y SUIS PROBLEMAS ACTUALES, traducción de Eugenio Imaz, Editorial Poblet, Buenos Aires, 1935;

KIRCHWEY, George W. - CAPITAL PUNISHMENT, in "Encyclopaedia of the social sciences", vol. $3 .^{\circ}$, pags. 192/195, The MacMillan Co, New York, 1937;

KOFFKA, K. - BASES DE LA EVOLUCION PSIQUICA, Espasa-Calpe Argentina, S. A.; Buenos Aires:

TAIY-HOLLEBECQUE, M. - L'EGLISE, in "L' K'volution Humaine des origines a nos jours", vol. II, pags. 215 e segts., Librairie Aristide Quillet, Paris, 1934;

LOMLROS0, Cesare - L'UOMO DELINQUENTE, riduzione di Gina Lombroso, Fratelli-Bocca, Editori, Torino, 1924;

IUDWIG, Emil - FREUD DESMASCARADO, traldução de Almir de Andrade, Livraria José Olimpyo, Rio, 1948;

LYRA, Roberto - PRESENTE Y FUTURO DEL DERECHO CRIMINAL, in "Revista del Centro Estudiantes de Derecho", de Montevideo, Tomo $17, \mathrm{n.} . \mathrm{o}^{\circ} \mathrm{0}, 1947$;

DO POSITIVISMO AO SOCIALISMO CRIMINAL, in "Revista de Derecho Penal", Buenos Aires, vol. 5. ${ }^{\circ}$, I, pags. 145 e segts;

MANFREDINI, Mario - EUTANASIA, verb. in "Dizionario di Criminologia” de Florian-Niceforo-Penide, vol. I, pgs. 338 e segts;

MARAÑOY, Gregorio - ESTUDIOS DE ENDOCRINOLOGIA, segunda edición; Espasa-Calpe Argentina, B. Aires, 1940; 
MAXWELL, J. - LE CRIME ET LA SOCIETE, Ernest Flammarion-Editeur, Paris, 1912;

MLLER, René Fullop - OS JESUITAS, tradução de Alvaro Franco, Editora Globo, 1946;

MINOW, Newton - THE ILLINOIS PROPOSAL TO CONFINE SEXUALLY DANGEROUS PERISONS, in "The Journal of Criminal Law and Criminology", vol. 40, pags. 186 e segts;

MIRA Y LOPEZ, Emilio - MANUAL DE PSICOLOGIA JURIDICA, Salvat Editores, S. A., Barcelona, 1932.

vat Editores, S. A., Barcelona, 1932;
- LOS FUNDAMENTOS DEL PSICOANALISIS, Editorial Americalee, LOS FUNDAM.

- LA PSIQUTATRIA EN LA GUERRA, Editorial Medico-quirurgica, Buenos Aires, 1944,

MOLINARIO, Alfredo J. - DERECHO PENAI, compilacion de Antonio Toscano, La Plata, 1943, Introducción:

ONTEIRO LOBATO - LITERATURA DE CÁRCERE, in Revista Brasileira de Criminologia, ano II, n.o 4, pag. 143;

MORAES, Evaristo de - CÁRCERES E FOGUEIRAS DA INQUISIÇ̃̃o, Athena Editora, Rio;

MOURA, Eros de - O HOMIĆ́DIO POR COMPAIXÃO, Coeditora Brasilica, Rio, 1940;

NICEFOR0, Alfredo - CRIMINOLOGIA, 2 vols., Fratelli Bocca-Editori, Milano, 1949 :

- L'IO PROFONDO E LE SUE MASCHERE, Fratelli Bocea-Editori,

Milano, 1949;
OTTO, M. C. - INTOLERANCE, in Encyclopaedia of the social sciences", vol. $8 .^{\circ}$, pag. 242 e segits:

PARDO, Ramon - PENA DE MORTE SOB O PONTO DE VISTA MEDICO E BIOLóGICO, tradução de Edith Torres, in "Revista de Direito Penal", vol. II, pag. 71, Jacinto-Eiditor, Rio;

PARMELEE, Maurice - CRIMINOLOGIA, versión de J. Cesar Cerdeiras, Editorial Reus, Madrid, 1925.

PELXOT0, Afrânio - CRIMINOLOGIA, Editora Guanabara, Rio

PEREIRA DA SILVA, Gastão - PARA COMPREENDER FREUd, $4 .^{2}$ edição, Civilização Brasileira S. A., Rio, 1935; - A PSICO-ANÁLISE, Adersen-Editores, Rio;

- NOVOS RUMOS DA. CRIMINOLOGIA, Atlantida Editora, Rio, 1934

PERRIN, Génil - PSICANÁLISE E CRIMINOLOGIA, traducão de Leonídio Ribeiro, Editora Guanabara, Rio, 1936

PESSINA, Enrico - ELEIIENTOS D EDERECHO PENAL, traducción de Gonzales del Castillo, Editorial Reus, Madrid, 1936, pags, 604 e segts;

POLLITZ, Paul - PSICOLOGIA: DO CRIMINOSO traducão de Néves Manta, Atlantida Editora, Rio, 1934;

PORTO-CARREIRO, J. P. - A PSICOLOGIA PROFUNDA OU PSICANALISE, Editora Guanabara, Rio;

PRINS, Adolphe - CIENCTA PENAL E DIREITO POSITTVO traducâo de Henrique de Carvalho, Jacinto-Editor, Rio:

PUGLIA, Ferdinando - MANUALE DI DIRITTO PENALE, vol. I. pags 356 e segts; Ernesto Anfossi Editore, Napoli, 1890;

RAMOS, Arthur - EDUCAÇÃO E PSICANÁLISE, Companhia Editora Nacional, S. Paulo, 1934;

- FREUD, ADLER, JUNG..., Editora Guanabara, Rio

REINACH, Salomén - ORFEO, versión de Domingo Vaca, Biblioteca Nueva, Buenos Aires;
REVISTA BRASILEIRA DE CRIMINOLOGIA - Direção do Prof. Roberto

Lyia, Rio;
REVISTA DE DIREITo PENAL - Direcão de Bertho Condé-Rio;

REVISTA DE DERECHO PENAL - Direcão do Prof. Eusebio Gomez,

Buenos Aires;

REY ARROJ0, M. L. - INTRODUCCION AL ESTUDIO DE LA CRIMINOLOGIA, Editorial "El Ateneo", B. Aires, 1945;

RUIZ FUNES, Mariano - ACTUALIDAD DE LA VENGANZA, Editorial Losada, S. A., Buenos Aires, 1944 .

- EVOLUCION DEL DELITO POLITICO, Editorial Hermes, Mexico, 1944;

- EL DELINCUENTE Y LA JUSTICIA, Editorial "La Facultad", Buenos Aires, 1944;

SCHILDER, Paul - PROBLEIMAS DO CRIME, in "A Moderna Psicanálise", tradução de Benjamim Gaspar Gomes, Editora Gertum Carneiro, Rio, pags. 451 e segts;

SOLER, Sebaistian - CONTRA A PENA DE MORTE, in "Rev. Brasileira de Criminologia, vol. I, fasc. $1 .^{\circ}$, pag. 148 ;

STEIN, Elbridge 'W. - HANDWRITING TESTIMONY IN A CRIMINAI. CONVICTION AND THE DISBABMENT OF A LAWYER, in "Journal of Criminal Law and Criminology", vol. 39, pags. 519 e segts:

SUTHERLAND, Edwin H. - PRINCÍPIOS DE CRIMINOLOGIA, tradução de Asdrubal Mendes Goncalves, Livraria Martins Editora, S. Paulo, 1948

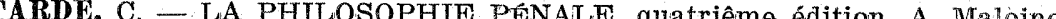
Editeur, Paris;

TAYLOR, F. Sherwood - PEQUENA HISTóRIA DA CÎ̂NCIA, traducão de Milton S. Rodrigues, Livraria Martins, S. Paulo;

TRATTNER, Emest B. - ARQUITETOS DE IDEIAS, traducão de L. Va-. landro, Editora Globo, Palegre, 1940;

VARRES, Donnedieu de - TRAITE DE DROIT CRIMINEL, troisième. édition, Librairie du Recueil Sury, Paris, 1947;

- A JUSTIÇA PENAL DE HOJE, tradução de Fernando de Miranda Saraiva \& Cia-Elditores, S. Paulo, 1938;

ALENTI, Veit - HISTORIA UNIVERSAL, Tomo I, pags. 319 e segts. Editorial Sudamericana, B. Aires, 1944

IDAL, Georges - COURS DE DROIT CRIMINEL ET DE SCIENCE PENITENTIAIRE, quatrième édition, Arthur Rousseau-Éditeur, Paris $1910,-$ pags. 619 e segts;

OLFAKL - DICCIONARIO FILOSOFICO, vols. II, pags. 327 e segts.; e II, pags. 79 e segts. - Editorial Araujo, Buenos Aires;

WRIGHT, Quincy - Comentários sôbre crimes contra a humanidade ê tribunais das Nações Unidas - in "Journal of Criminal Law and Criminology", vol. 40 , pags. 622 e segts;

Livramento, R. S., 30 de Julho de 1950 


\section{RELATÓRIO E PARECER}

Relator: PLAUTO D'AZEVEDO

Magnífico considero o trabalho de autoria do Dr. Érico Maciel Filho, ilustre Bacharel em Direito, apresentado ao Congresso Jurídico - "DA PENA DE MORTE e DA NECESSIDADE DE SUA PROSCRIÇÃO POR CONSTITUIR UM SUPREMO ATENTADO' À CIVILIZAÇÃO".

Revela o Autor ser, em verdade, um estudioso através das razões fundamentadas e comprovadas em farta e selecionada bibliografia.

Merece esr lido com atenção, detidamente, e constitui grande prazer inteletual, que me foi proporcionado.

O talentoso Bacharel, usando das palavras de Mariano Ruiz Funes, discute, com proficiência, o problema humano, jurídico, moral e sentimental, da pena de morte.

Possuidor de cultura jurídica, mostra constituirem negação do Díreito métodos repressivos de gravidade ou irreparabilidade.

A pena de morte, diz, é uma medida ineficaz e inadmissível em uma sociedade civilizada.

Após, faz um histórico da pena de morte, indicando os meios bárbaros do passado e faz referências aos instrumentos da política repressiva que Ruiz Funes denomina "defesa social pelo terror".

A corrente doutrinária orientada por Gabriel Tarde justifica a pena de morte:

a) por ser mais intimidante e, em conseqüência, a que mais contribui para demover as pessoas da prática do crime (prevenção geral);

b) ser mais econômica que a de prisão;

c) ser meio excelente de seleção artificial;

d) caracterizar-se, pela sua irreparabilidade, como uma garantia contra o perdão judicial ou a possível fuga dos condenados.

Isso, porém, foi combatido pelas maiores autoridades - Bentham, Carrara, Cuello Calón, Becaria, Dorado Montero, Florian, Asúa, Ruiz Funes, citados pelo Autor da tese, que lembra clamar o interêsse social pelo aperfeiçoamento dos métodos de assistência a todos os membros da sociedade, - e nunca pelo menosprêso ostensivo do mais sagrado dos direitos, que é o direito á Vida.

Cita os erros judiciários levando à morte inocentes, com numerosos exemplos.
Repele a pena de morte para os crimes comuns e políticos.

E mesmo para os hoje denominados "contra a humanidade" praticados por dirigentes de grandes massas humanas ou por seus subordinados.

Depois de muitas outras considerações e de argumentos sólidos, - ilustre Autor do trabalho sugere o seguinte:

"O Congresso Jurídico condena e repele a pena de morte, como método punitivo-repressivo de quaisquer atividadés delituosas, recomendando a supressão de tal pena dos Códigos Penais, e a absoluta abstenção do seu uso - , por contrariar o interêsse social e o sentido da $\mathrm{Ci}$ vilização".

O trabalho do dr. Erico Maciel Filho é humano e jurídico.

Não devemos esquecer, ainda, o preceito bíblico:

"Porque Tu, SENHOR, és o que tens o poder da Vida e da Morte".

Considero, pois, merecedor de aplausos e de figurar nos Anais do Congresso Jurídico pelo seu incontestável valor.

Pôrto Alegre, 21 de agosto de 1950. 